\title{
SLIDING BONES: MOVEMENT OF SKELETAL MATERIAL OVER SMITH CREEK PLAYA IN NEVADA AND ITS TAPHONOMIC AND PALEONTOLOGIC IMPLICATIONS
}

\author{
George D. Baumgardner ${ }^{1,2}$ and Brian S. Shaffer
}

\begin{abstract}
In July 2013, a unique type of movement was noted of cattle (Bos taurus) bones across the surface of Smith Creek Valley Playa, in central Nevada. Portions of 3 skeletal elements and 2 sections of articulated elements were found at the ends of shallow, linear, furrow-like trails inscribed in the playa surface. These trails, with their skeletal material, are similar to those produced by the phenomenon described as "racing" or "sailing rocks" that is best documented from Racetrack Playa in Death Valley, California. As has been recently observed for the rocks of Racetrack Playa, the material here was probably moved by a combination of wind acting on ice floating on liquid water. This is the first report of such movement of objects from Smith Creek Playa and represents a previously unreported mechanism for taphonomic transport of skeletal material.
\end{abstract}

RESUMEN._En Julio de 2013, un tipo único de movimiento de huesos bovinos (Bos taurus) fueron observados sobre la superficie de una Playa seca en el Valle de Smith Creek la cual se encuentra en la parte central del estado de Nevada, EUA. Fragmentos de tres esqueletos óseos y dos secciones de elementos articulados fueron encontrados descansando al término de surcos o senderos inscritos en la superficie de una playa seca sin intervensión alguna. Estos senderos con sus restos óseos se semejan al fenómeno conocido como "piedras viajeras ó piedras rodantes" el cual ha sido documentado como Racetrack Playa del Párque Nacional de Death Valley (Valle de la Muerte) en California, EUA. Como ha sido recientemente demostrado por las "piedras viajeras o rodantes" de Racetrack Playa, el movimiento aqui fué probablemente causado por medio de una combinacion de viento actuando con hielo flotando sobre agua liquida. Éste es el primer informe de tal movimiento ó desplasamiento de objetos sobre la playa seca de Smith Valley, el cuál representa un mecanismo tafonómico no reportado previamente sobre el transporte de material óseo.

Transport of postmortem animal remains has been documented to occur by numerous means including glacial, aquatic, geological, eolian, biological, and cultural processes (e.g., Schäfer 1972, Behrensmeyer and Hill 1980, Bonnichsen and Sorg 1989, Weigelt 1989, Lyman 1994). Herein we present evidence for a previously unreported dispersal process for osteological material similar to the phenomenon known as "racing rocks" (also known as sliding rocks, sailing rocks, and scrapers).

Such movement has been reported for at least 11 playa lake beds in California and Nevada (Stone 1967, Wehmeier 1986, remaining sources summarized by Messina 1998), as well as in Utah (Lines 1979), Africa (Di Cesare and Pratelli 1967, Eriksson et al. 1996), and Spain (Sanz-Montero and Rodríguez-Aranda 2013). The best-known and best-documented occurrence of this phenomenon is on Racetrack Playa in California's Death Valley National Park (Messina 1998, Messina and Stoffer 2000).
Rocks at this site ranged in size from pebbles to boulders, weighing up to an estimated 318 $\mathrm{kg}$. Trails varied from $1.56 \mathrm{~m}$ to $880.73 \mathrm{~m}$ long. They were often straight but also curved, undulated, went in circles, and even abruptly reversed direction. Nearly all objects reported from other sites have been lithic, although some nongeologic items (twigs, bushes, metal, burro droppings, bottles, bricks) have also been noted (e.g., Clements 1952, Stanley 1955, Motts 1969, Sanz-Montero and Rodríguez-Aranda 2013).

Causes of movement have been speculated about in the literature since at least the late 1940s (MacAllister and Agnew 1948). Recently favored explanations involve various combinations of water, wind, low temperature, and microbial mats (e.g., Messina and Stoffer 2000, Lorenz et al. 2011, Kletetschka et al. 2013, SanzMontero and Rodríguez-Aranda 2013, Lorenz et al. 2014, Norris et al. 2014). All of these need water and wind. Water in liquid and/or ice

\footnotetext{
${ }^{1}$ Nevada State Museum, Carson City, 600 North Carson Street, Carson City, NV 89701

2E-mail: gbaumgardner@nevadaculture.org
} 
form holds, pushes, or helps support objects. Although not always stated, it is implicit in all explanations that liquid water softens the playa substrate. This reduces surface tension allowing moving objects to drag the substrate, creating furrows. Wind provides the propulsive force by pushing on a medium (i.e., liquid water, ice, microbial mats) that in turn pushes or carries objects.

There are currently 3 primary mechanisms by which movement has been documented or posited. The first was recently observed on Racetrack Playa, where nearly all rocks that moved were pushed or bulldozed by thin sheet ice suspended on liquid water. In this option, the objects were not surrounded by ice (Lorenz et al. 2014, Norris et al 2014). In the second manner, an object is encased by ice floating on liquid water. This was demonstrated by Lorenz et al. (2011) in a laboratory experiment, observed for one rock on Racetrack Playa (Lorenz et al. 2014), and concluded from a field study of Racetrack Playa (Kletetschka et al. 2013). The third mechanism involves pooled liquid water in which microbial mats buoy up objects and provide additional reduction of surface friction with the playa (Sanz-Montero and Rodríguez-Aranda 2013). Unlike in other investigations, these authors noted that because of diurnal temperature variations, this water's salt content, and its high specific heat capacity, "movement of objects by ice . . . is ruled out because water freezing does not occur at the negative temperature values recorded in the area" (Sanz-Montero and Rodríguez-Aranda 2013, p. 61).

Since June 2000, GDB has conducted natural history field research on and around Smith Creek Playa in Smith Creek Valley (42 km west-southwest of Austin, Lander County, Nevada). Smith Creek Valley has a north-tosouth orientation. It varies in approximate width across the western and eastern crests of its mountain ranges from $16 \mathrm{~km}$ to $32 \mathrm{~km}$ and across its floor from $13 \mathrm{~km}$ to $16 \mathrm{~km}$. Maximum elevation of the surrounding mountains is $3155 \mathrm{~m}$ atop North Shoshone Peak, with several peaks exceeding $2745 \mathrm{~m}$ (Everett and Rush 1964). Lowest elevation is on the playa floor at $1844 \mathrm{~m}$ (Everett and Rush 1964). Smith Creek Playa lies roughly in the center of the valley and consists of 2 hydrologically connected portions. The much larger portion discussed here is $11.5 \mathrm{~km}$ long by $4-4.8 \mathrm{~km}$ wide. Its long axis is oriented northeast to southwest. Holocene faulting has resulted in the playa floor being tilted downward to the west. The eastern half slopes at a rate of $30.5 \mathrm{~cm}$ per 1.6 $\mathrm{km}$. The western half is less steep because of a depositional wedge (Thomas et al. 1989). This playa is considered very smooth by the many visitors that travel here to pilot wheeled sailcraft over its expanse.

Farming and ranching occur locally and cattle and horses roam the area. A number of human recreational activities (e.g., camping, visitation of hot springs, land-sailing) occur on and around the playa. The playa surface is frequently traversed by sailcraft and motorized vehicles. Larger wildlife species seen here that are potential scavengers include the American badger (Taxidea taxus) and coyote (Canis latrans).

Environmental data were obtained from a National Weather Service weather station located on the western edge of the valley $5.2 \mathrm{~km}$ west-northwest from and $52 \mathrm{~m}$ higher in elevation than the study site (Meso-West 2013). Weather conditions can vary greatly over short periods and annually (Meso-West 2013, GDB personal observation). The following values, except where otherwise noted, are for the year preceding discovery of the bones and trails (13 July 2012 to 13 July 2013).

During this period, temperatures ranged from $-27^{\circ} \mathrm{F}$ to $101{ }^{\circ} \mathrm{F}\left(-32.8^{\circ} \mathrm{C}\right.$ to $\left.38.9^{\circ} \mathrm{C}\right)$. Temperatures were $\leq 32{ }^{\circ} \mathrm{F}\left(0{ }^{\circ} \mathrm{C}\right)$ on $191 \mathrm{~d}$ (months of September 2012 to May 2013) and $\leq 10{ }^{\circ} \mathrm{F}\left(-12.2{ }^{\circ} \mathrm{C}\right)$ on $44 \mathrm{~d}$ (November 2012 to February 2013). The coldest months were December 2012 and January 2013. Temperatures were $\geq 90{ }^{\circ} \mathrm{F}\left(32.2^{\circ} \mathrm{C}\right)$ on $39 \mathrm{~d}$ (July and August 2012, June and July 2013). June and July 2013 were the hottest months, with temperatures $\geq 100{ }^{\circ} \mathrm{F}\left(37.8^{\circ} \mathrm{C}\right)$.

Smith Creek Playa is often at least partially covered by water from summer rains and receives snow in the winter. Accumulated precipitation for 3-d periods varied from 0.01 to 0.50 inches $(0.3$ to $12.7 \mathrm{~mm})$ and was $\geq 0.10$ inches $(2.5 \mathrm{~mm})$ for 17 such periods. Precipitation of $\geq 0.10$ inches $(2.5 \mathrm{~mm})$ occurred during all months except September and October 2012 and June and July 2013. On 1 September 2013 (1 d after the bones and tracks were last studied) a rainfall of 0.39 inches $(9.2 \mathrm{~mm})$ occurred that resulted in flooding of a portion of the playa to an estimated depth of $8 \mathrm{~cm}$ (GDB personal observation). 
Wind in the area varies greatly in speed and direction. Sustained wind speeds frequently peaked between 5 and $20 \mathrm{mi} / \mathrm{h}(8 \mathrm{~km} / \mathrm{h}$ and 32 $\mathrm{km} / \mathrm{h}$ ) with occasional highs of 25 to $35 \mathrm{mi} / \mathrm{h}$ (40 to $56 \mathrm{~km} / \mathrm{h}$ ). Speeds for wind gusts generally varied from 15 to $35 \mathrm{mi} / \mathrm{h}$ ( 24 to $56 \mathrm{~km} / \mathrm{h}$ ) with occasional highs of 40 to $50+\mathrm{mi} / \mathrm{h}(64$ to $80+$ $\mathrm{km} / \mathrm{h})$. Sustained winds of $20+\mathrm{mi} / \mathrm{h}(32+\mathrm{km} / \mathrm{h})$ and wind gusts of $30+\mathrm{mi} / \mathrm{h}(48+\mathrm{km} / \mathrm{h})$ were frequent throughout the year. Highest peak sustained winds of 30 to $35 \mathrm{mi} / \mathrm{h}$ (48 to 56 $\mathrm{km} / \mathrm{h})$ and wind gusts of $52 \mathrm{mi} / \mathrm{h}(84 \mathrm{~km} / \mathrm{h})$ occurred in November and December 2012. Wind direction during the study period was fairly evenly distributed throughout all degrees of the compass.

Since 2000, animal carcasses and scattered bones have been frequently observed on the playa by GDB. Most material has consisted of cattle (Bos taurus) remains but a few horses (Equus caballus, also referred to as Equus ferus), have also been noted. Remains ranged from incompletely articulated skeletons having some dried skin and hair to partial elements that were bleached white and had considerable degradation.

On 13 July 2013, a bone of a large animal was discovered at one end of a shallow trail inscribed in the playa's surface (Fig. 1). Further investigation revealed portions of 3 skeletal elements and 2 sections of articulated elements associated with 5 furrow-like trails (Table 1; Figs. 1-3). This material was located north to northwest of a group of livestock carcasses (at $\left.39^{\circ} 17.148^{\prime},-117^{\circ} 31.596^{\prime}\right)$ that had been observed by GDB for 4 years.

Presumed stop points of these trails were obtained with a handheld Garmin eTrex Legend HCx GPS unit held over each partial element and section. The GPS accuracy that day varied $\pm 3 \mathrm{~m}$. These points were marked with stakes driven into the ground $0.5 \mathrm{~m}$ to the side of the trail. The trail was followed until it could no longer be seen, and a second GPS waypoint was taken to designate the presumed start point. Minimum distances between start and stop points were obtained using the "Go To" function of the GPS. Magnetic bearings of paths were measured using a Suunto MCA-D IN compass. Photos were taken with a digital camera. At the end of this initial data collection the stakes were removed to avoid their becoming traffic hazards. General shape of trails was noted, but detailed characterization of their outline was not made due to the threat of lightning. Two days later the bones were taken to the lab to be identified and weighed. On 4 August 2013, the material was returned to its stop points. Original positions were determined using GPS readings, matching projections on bones to dimples in the ground, and photo records. Subsequent trips (14 August 2013 and 31 August 2013) were made to monitor object and trail status.

These bones were identified as cattle using Sisson and Grossman (1953) and Adams and Crabtree (2012). All material was degraded due to climatic effects (weathering) and some degree of breakage. Specific taphonomic characterization of the skeletal material is as follows:

Right humerus (nearly complete; Fig. 1) $990 \mathrm{~g}$. The proximal portion of the lateral tuberosity was missing. Small areas of the periosteum and connective tissue were present on many surfaces. Windowing (exposing the medullary cavity) was present on the proximal anterior-medial portion of the shaft. Fracture surfaces were irregular, but showed rounding/ smoothing. Weathering consisted of bleaching, with posterior surfaces exhibiting fineline longitudinal and traverse fracturing and planar flaking.

Left humerus (distal two thirds complete) $564 \mathrm{~g}$. The humeral head and a portion of shaft were missing above the deltoid tuberosity. This was the least weathered specimen. It was greasy (probably from bone collagen) and had an adhering layer of brown sediment and connective tissue on multiple locations. The fracture edge was angular and irregular with abrasion on the anterior and proximal surfaces. There were no marks to indicate the cause of breakage. No significant bleaching or weathering was noted. This specimen is notably smaller than the right humerus indicating that at least 2 individuals contributed to the material that had trails.

Thoracic vertebra (nearly complete, specific anatomical positioning was not determined; Fig. 2)—173 g. The distal tip of the spinous process was abraded with minimal damage to left lateral process and other protuberances. Weathering was evidenced by a bleaching white of the bone but there was no evidence of fine-line fracturing or planar flaking. The start point for this vertebra was very near that of the 5 thoracic vertebrae described below plus the former articulated well with the last of the thoracic series. All this material was probably from the same animal. 


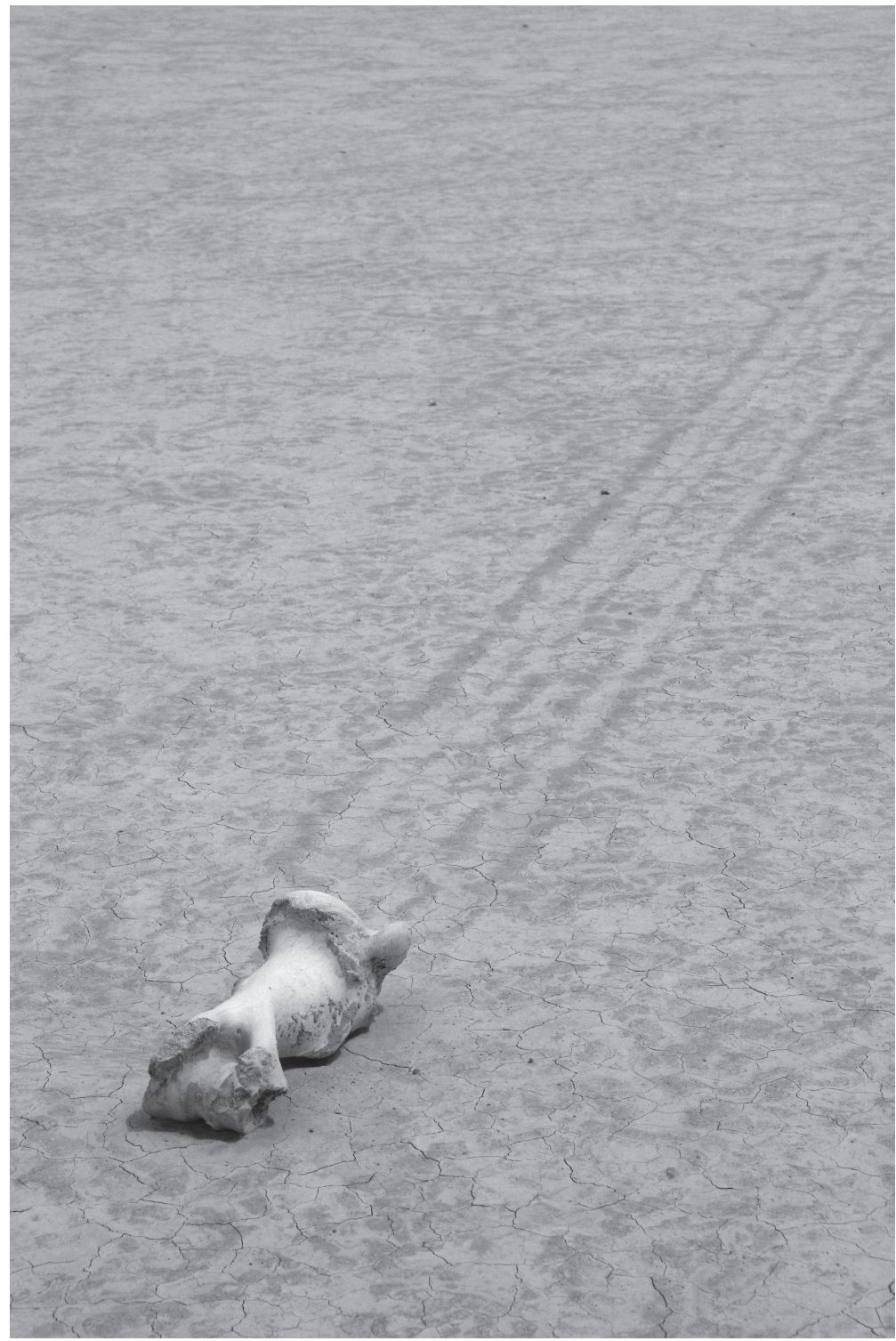

Fig. 1. Right humerus of a cow at end of furrow inscribed in playa surface.

Five thoracic vertebrae, all articulated (nearly complete, specific anatomical positioning of vertebrae was not determined) and left rib (proximal end, articulated with second and third vertebrae in sequence) $-1740 \mathrm{~g}$. Connective tissue was present between the centra and between the rib and the vertebrae. The distal spinous processes were abraded with angular fractures. The rib consisted of the head and neck, and a small portion of the proximal body. The fracture on the rib was irregular and angular. There were no marks to indicate the cause of breakage. Protuberances exhibited superficial damage exposing underlying cancellous bone. Weathering consisted of bleaching with primarily longitudinal fineline cracking on the vertebrae and rib.

Axis to first thoracic vertebra, all articulated (nearly complete) - $1880 \mathrm{~g}$. The termini of the spinous and most transverse processes were missing and exhibited dry bone, and irregular and stair-step breakage/abrasion. The spinous processes were progressively more damaged to the posterior. Weathering consisted 
of bleaching, minor fine-line longitudinal and transverse fracturing, and planar flaking.

There were 2 types of degradation observed on these specimens (i.e., weathering and mechanical breakage). Although much of this degradation was probably due to general weathering, the mechanical breakage on the edges and protuberances is less common and of more interest. This material exhibited no tooth marks to indicate breakage by carnivores and no tool marks or fracturing (Johnson 1985) that could be directly attributed to human activity. With no other identified causes, it seems likely that most mechanical damage was incurred due to friction with the surface during movement across the playa, such as seen on the edges and protuberances as well as the "windowing" of the right humerus. This damage was minor compared to the loss of bone exhibited by the left humerus (missing proximal end) and rib (missing everything but vertebral end). No marks were identified that would account for such loss and if it had been present, it had been obliterated by subsequent damage to the bones and fracture surfaces.

Furrows and ridges in the trails correlated with bone contours. Furrow depth was estimated at $1 \mathrm{~mm}$ to $2 \mathrm{~mm}$. Trails were straight or curved mildly but did not show the major directional variation observed for some rocks by Messina and Stoffer (2000). Straight-line distance between start and stop points ranged from $15 \mathrm{~m}$ to $117 \mathrm{~m}$ (Table 1). Paths were oriented north-northwest from $317^{\circ}$ to $334^{\circ}$ true (Table 1, Fig. 3) and came from the general direction of the previously mentioned livestock carcasses. This similarity of direction indicates the propulsive force (wind and/or liquid water) was traveling in the same general direction when the material moved. It is possible these objects moved during the same propulsive episode but it cannot be determined if they did so simultaneously. Nor can it be determined if these objects moved in one continuous event. No depressions in the substrate (called "sitz marks" by Sanz-Montero and RodríguezAranda 2013) could be observed among the trails to indicate that these objects had stopped for a time during their journeys; however, the furrows were quite faint and such marks would have been very obscure. Trails for the single thoracic vertebra and the series of 5 thoracic vertebrae cross near their start points suggesting that despite their original proximity to one 


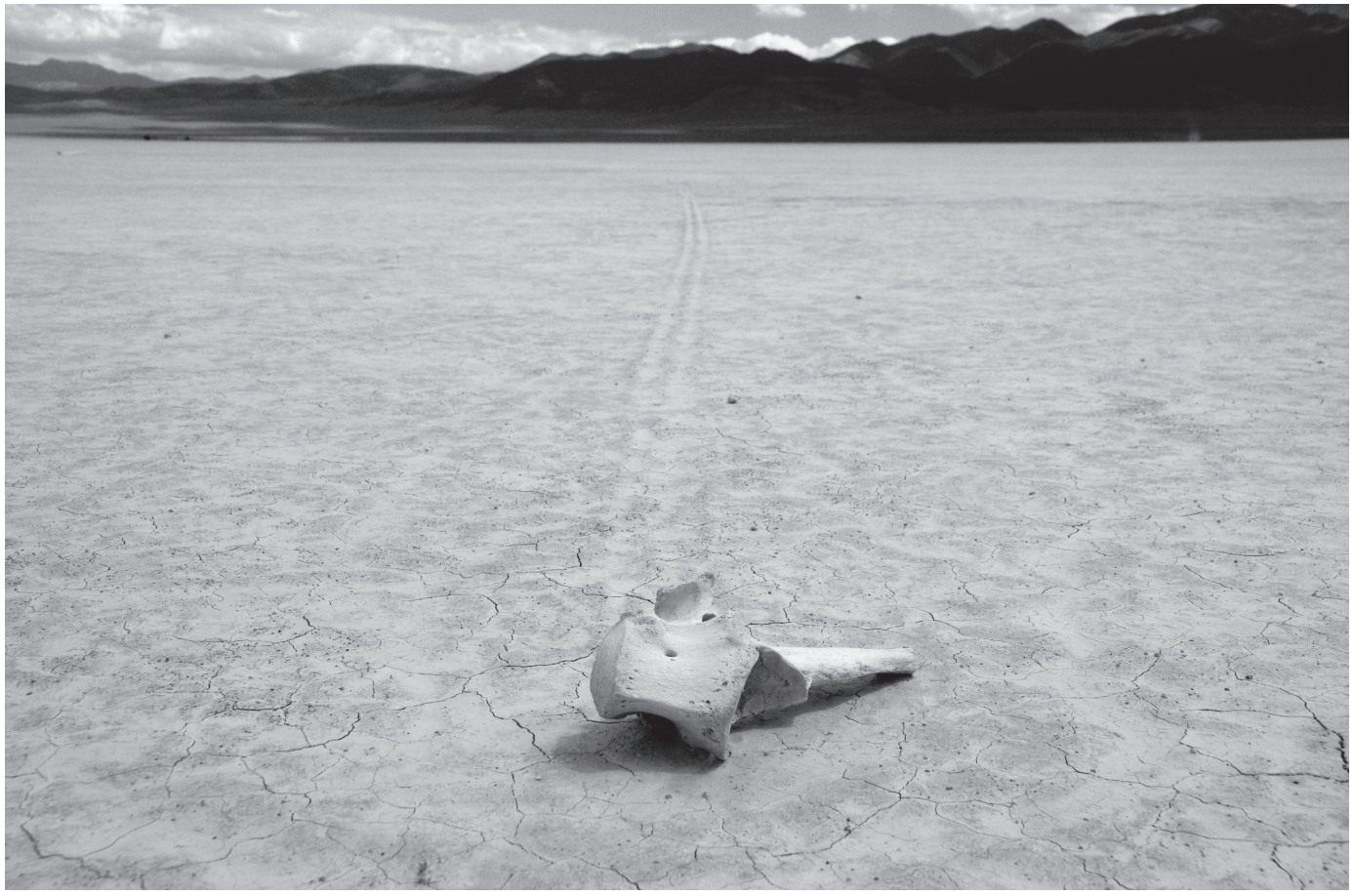

Fig. 2. Thoracic vertebra of a cow at end of furrow inscribed in playa surface.

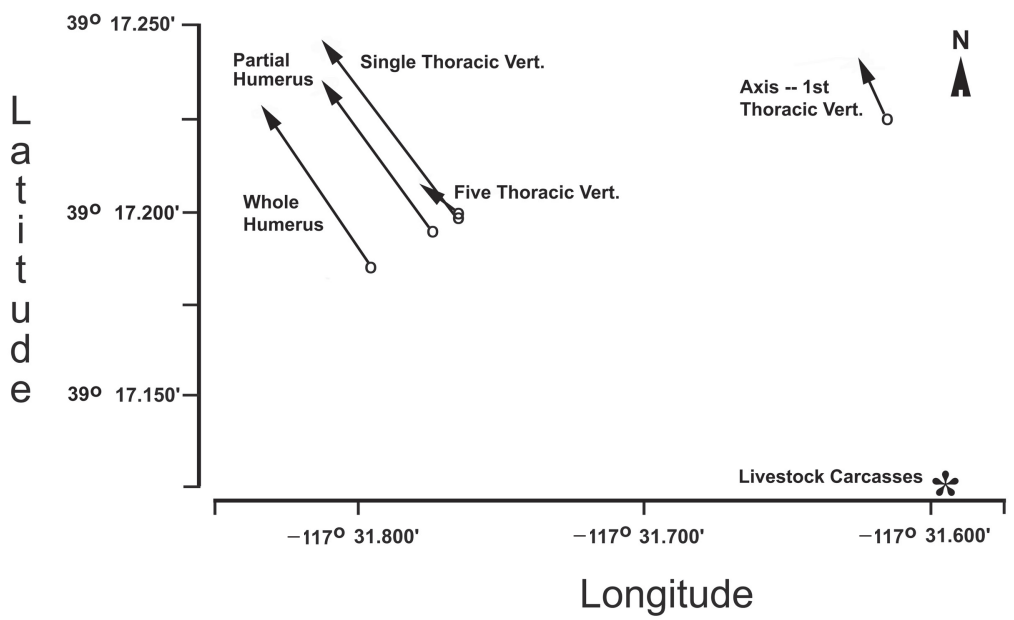

Fig. 3. Plot of start $(O)$ and stop $(\mathbf{\Delta})$ points with the arrowheads showing general trail path and direction of travel for skeletal elements. Location of the livestock carcasses that are the possible source of this skeletal material is denoted by an asterisk $(*)$.

another they were not moved by a single ice sheet. Unfortunately the intersection of these trails was so faded and it could not be determined which trace formed first. Polygonal desiccation cracks in the playa surface cut through the furrows without being deformed in the direction of object travel, indicating that the playa dried after trail formation (Figs. 1, 2).

Distances between trail start points and the carcasses mentioned above ranged from $150 \mathrm{~m}$ 
to $244 \mathrm{~m}$. It is likely the material with trails originated from the carcasses but the reason for its movement to the start points can only be speculated upon (scattering by scavengers, sliding/racing, human intervention, etc.). Regardless of how this material got to the start of the furrows, it is clear from their trails and the absence of wheel tracks, footprints, and paw prints that it was not moved by people or nonhuman animals.

The furrows had faded noticeably by 4 August 2013, and the holes of the stakes were in-filling with substrate. Rainfall occurred in the area on at least one occasion between the 4 August 2013 and 31 August 2013 visits. On 31 August 2013 (last visit) the most obvious trail (right humerus) was quite faint and all other stake holes and trails were gone. Because there had been no visits by the authors to the playa for nearly a year prior to discovery of the trails, it is uncertain how long these tracks were present before their initial observation. However, their rapid fading after discovery implies they were likely shortlived compared to those on Racetrack Playa, where object trails can last up to a few years (Messina and Stoffer 2000). In the 13 years GDB has traversed this playa and examined the bones on its surface, no other such trails have been observed. The frequency of precipitation here probably renders such trails rather ephemeral.

A major difference between this skeletal material and its lithic counterparts relates to their very different compositions. Because these specimens contain cavities that can trap air they should be more easily buoyed up by liquid water or ice compared to geologic material. This should in turn result in less force being required to move bone compared to rock of similar size. This difference could be important for any movement mechanisms involving liquid water.

These sliding bones directly resemble their racing rock counterparts and probably moved by similar mechanisms. Timing of movement and its precise mechanisms cannot be determined from available evidence; however, comparison of what is known with the various movement explanations should indicate the likely causes and timing of this phenomenon. Nearly all conditions demonstrated or proposed to allow for object movement occur at this site. Pooled water and wind are common and freezing temperatures can occur during much of the year. It is unknown if microbial mats grow in water that pools on this playa; however, GDB has never seen standing water here for more than $3 \mathrm{~d}$, no such growth has been observed during these times, and no cyanobacteriological staining, as described by Sanz-Montero and Rodríguez-Aranda (2013), has been evident on objects lying on the playa.

Given the presence of conditions required for movement involving ice and the lack of evidence for microbial mats, this material probably moved by one or both of the previously summarized means involving wind-blown sheet ice floating on liquid water (e.g., Lorenz et al. 2011, Kletetschka et al. 2013, Lorenz et al. 2014, Norris et al. 2014). Whether these bones moved in an encasement of ice (Lorenz et al. 2011, Kletetschka et al. 2013) or were free of it as they were being "bulldozed" (Norris et al. 2014) cannot be determined from the evidence available.

This movement represents a previously unreported avenue for dispersal and degradation of osteological material and should be considered in future taphonomic and paleontologic studies. It is not infrequent for fossil remains to be found in lake deposits of western North America (Grayson 1993, p. 156-157, table 7-1). If one applies the potential for movement seen by the racing rocks of Death Valley (up to $880.73 \mathrm{~m}$; Messina 1998) to skeletal elements, the remains of an organism could be scattered over considerable distance by means not previously considered.

The authors thank Patricia DeBunch of Eetza Research Associates in Reno, Nevada, for her translation of the abstract into Spanish; Jeanette McGregor, John K. Salser; 2 anonymous reviewers; and the editors of this journal for their contributions to this manuscript. This work is dedicated to the memory of D. Gentry Steele. We wish he could have read this article.

\section{Literature Cited}

Adams, B., AND P. CRABTreE. 2012. Comparative osteology: a laboratory and field guide of common North American animals. Academic Press, Oxford, United Kingdom. 460 pp.

Behrensmeyer, A.K., AND A.P. Hill. 1980. Fossils in the making: vertebrate taphonomy and paleoecology. University of Chicago Press, Chicago, IL. 345 pp.

Bonnichsen, R., AND M.H. Sorg. 1989. Bone modification. University of Maine, Orono, ME. 535 pp. 
Clements, T.D. 1952. Wind-blown rocks and trails on Little Bonnie Claire Playa, Nye County, Nevada. Journal of Sedimentary Research 22:182-186.

Di Cesare, F., and W. Pratelli. 1967. "Moving stones" of Tunisian Sahara (Bir Pistor). Page 273 in L. Martin, editor, Petroleum Exploration Society of Libya, 9th annual field conference, guidebook to the geology and history of Tunisia. Guidebook to the geology and history of Tunisia 66.

Eriksson, P.G., E.B. Foertsch, C.P. Snyman, J.H. LingenFELDER, B.E. Beukes, AND W. Cloete. 1996. Windblown rocks and trails on a dry lake bed; an alternative hypothesis. Journal of Sedimentary Research 66: 36-38.

Everett, D.E., AND F.E. Rush. 1964. Ground-water appraisal of Smith Creek and Ione valleys, Lander and Nye counties, Nevada. Nevada Department of Conservation and Natural Resources Ground-Water Resources Reconnaissance Series Report 28, Carson City, NV.

Grayson, D.K. 1993. The desert's past: a natural prehistory of the Great Basin. Smithsonian Institution Press, Washington, DC. 384 pp.

Johnson, E. 1985. Current developments in bone technology. Advances in Archaeological Method and Theory 8:157-225.

Kletetschia, G., R. LeB. Hooke, A. Ryan, G. Fercana, E. McKinney, And K.P. Schwebler. 2013. Sliding stones of Racetrack Playa, Death Valley, USA: the roles of rock thermal conductivity and fluctuating water levels. Geomorphology 195:110-117.

LiNES, G.C. 1979. Hydrology and surface morphology of the Bonneville Salt Flats and Pilot Valley Playa, Utah. USGS Water Supply Paper. 2057. U.S. Government Printing Office, Washington, DC.

Lorenz, R.D., B.K. Jackson, J.W. Barnes, J. Spitale, and J.M. KELLER. 2011. Ice raft not sails: floating the rocks at Racetrack Playa. American Journal of Physics 79: $37-42$.

LORENZ, R.D., J.M. NORRIS, B.K. JaCKSON, R.D. NORRIS, J.W. Chadbourne, and J. Ray. 2014. Trail formation by ice-shoved "sailing stones" observed at Racetrack Playa, Death Valley National Park. Earth Surface Dynamics, Discussions 2:1005-1022.

Lyman, R.L. 1994. Vertebrate taphonomy. Cambridge University Press, New York, NY. 552 pp. dx.doi.org/ 10.1017/CBO9781139878302

MacAllister, J.F., AND A.F. AgNew. 1948. Playa scrapers and furrows on Racetrack Playa, Inyo County, California. Bulletin of the Geological Society of America 59:1377.

Meso-West. 2013. Weather data for Desatoya Mountains, Nevada. Division of Atmospheric Sciences, University of Utah, Salt Lake City, UT. http://mesowest.utah.edu
Messina, P. 1998. The sliding rocks of Racetrack Playa, Death Valley National Park, California: physical and spatial influences on surface processes. Doctoral dissertation, City University of New York, New York, NY. 372 pp.

Messina, P., AND P. Stoffer. 2000. Terrain analysis of the Racetrack Basin and the sliding rocks of Death Valley. Geomorphology 35:253-265.

MotTs, W.S. 1969. Chapter 7: Some hydrologic and geologic processes influencing playa development in the western part of the Basin and Range Province, United States. Pages 237-269 in W.S. Motts, editor, Geology and hydrology of selected playas in Western United States. Geology Department, University of Massachusetts, Amherst, MA

Norris, R.D., J.M. Norris, R.D. Lorenz, J. Ray, and B. JACKSON. 2014. Sliding rocks on Racetrack Playa, Death Valley National Park: first observation of rocks in motion. PLOS ONE 9:1-11. dx.doi.org/10.1371/ journal.pone.0105948

Sanz-Montero, M.E., and J.P. RodrígueZ-Aranda. 2013. The role of microbial mats in the movement of stones on playa lake surfaces. Sedimentary Geology 298:53-64.

SCHÄFER, W. 1972. Ecology and palaeoecology of marine environments. University of Chicago Press, Chicago, IL.

Sisson, S., AND J.D. Grossman. 1953. The anatomy of the domestic animals. W.B. Sanders Company, Philadelphia, PA. 2130 pp.

STANLEY, G.M. 1955. Origin of playa stone tracks, Racetrack Playa, Inyo County, California. Geological Society of America Bulletin 66:1329-1350.

STONE, R.O. 1967. Unique playa scraper and furrow near McKittrick, California. Meeting abstract. American Association of Petroleum Geologists Bulletin 51: $482-483$.

Thomas, J.M., S.M. Carlton, and L.B. Hines. 1989. Ground-water hydrology and simulated effects of development in Smith Creek Valley, a hydrologically closed basin in Lander County, Nevada. U.S. Geological Survey Professional Paper 1409-E.

WeHmeier, E. 1986. Water induced sliding of rocks on playas: Alkali Flat in Big Smokey Valley, Nevada. Catena 13:197-209.

WeigeLt, J. 1989. Recent vertebrate carcasses and their paleobiological implications. University of Chicago Press, Chicago, IL. 204 pp.

Received 27 June 2014 Accepted 11 February 2015 